\title{
$O$-Iodoxybenzoic Acid in Water: Optimized Green Alternative for Multicomponent One-Pot Synthesis of 2-Amino-3,5-dicarbonitrile-6-thiopyridines
}

\author{
Santosh Takale, ${ }^{a}$ Jaidas Patil, ${ }^{a}$ Vikas Padalkar, ${ }^{b}$ Rajaram Pisal ${ }^{a}$ and Atul Chaskar ${ }^{*, c}$ \\ ${ }^{a}$ Changu Kana Thakur Research Centre, 410206 Navi Mumbai, India \\ ${ }^{b}$ Institute of Chemical Technology, Matunga, 400019 Mumbai, India \\ ${ }^{c}$ Department of Chemistry, National Taiwan University, 10617 Taipei, Taiwan
}

\begin{abstract}
Uma reação multicomponente do tipo one-pot de aldeído aromático, melanonitrilo e tiofenol na presença de ácido iodoxibenzóico (IBX) em meio aquoso forneceu 2-amino-3,5-dicarbonitrilo6-tiopiridina em bons a excelentes rendimentos. Eventualmente, um catalisador poderia ser facilmente recuperado e reutilizado sem perda de sua propriedade catalítica.
\end{abstract}

A multicomponent one-pot reaction of aromatic aldehyde, malononitrile and thiophenol in the presence of iodoxybenzoic acid (IBX) in aqueous media furnished 2-amino-3,5-dicarbonitrile6-thiopyridine in good to excellent yield. Eventually, a catalyst could be easily recovered and reused without loss of its catalytic property.

Keywords: $O$-iodoxybenzoic acid, green catalyst, thiopyridines, aqueous media, multicomponent reactions

\section{Introduction}

The nitrogen heterocycles have been intensively investigated in past decades due to their ubiquitous presence in biologically active compounds and multifarious natural products. Pyridine ring system represents the major class of nitrogen heterocycles and its analogues exhibited diverse biological and physiological activities, such as antibacterial, antiviral, anti-inflammatory, antitumoural and antioxidant. These potential therapeutic applications made it as a privileged scaffold..$^{1-3}$

2-Amino-3,5-dicarbonitrile-6-thiopyridine derivatives are not only used as anti-prion, ${ }^{4,5}$ anti-hepatitis B virus, ${ }^{6}$ anti-bacterial $^{7}$ and anti-cancer ${ }^{8}$ agents but also are used as potassium channel openers for the treatment of urinary incontinence. ${ }^{9}$

Recently, it is being used in treatment of Parkinson's disease, hypoxia, asthma, kidney disease, epilepsy, cancer ${ }^{10}$ and creutzfeldt-jacob disease. ${ }^{11}$ In view of their high significance, many methodologies have been developed for the construction of the pyridine skeleton. Various basic catalysts like piperidine, $\mathrm{Et}_{3} \mathrm{~N}$ $\left(\mathrm{N}\left(\mathrm{CH}_{2} \mathrm{CH}_{3}\right)_{3}\right)$, DABCO (1,4-diazabicyclo[2.2.2]

*e-mail: achaskar25@gmail.com octane), ${ }^{5,12}$ morpholine, thiomorpholine, pyrrolidine, $N, N$-DIPEA ( $N, N$-diisopropylethylamine), pyridine, 2,4,6-collidine (2,4,6-trimethylpyridine), DMAP (4-dimethylaminopyridine), aniline, $N$-methylaniline, $N, N$-dimethylaniline and $N, N$-diethylaniline have been employed for this multicomponent reaction. ${ }^{12}$ In addition, basic ionic liquids 1-methyl-3-butylimidazolium hydroxide, [bmim]OH, ${ }^{12}$ DBU (1,8-diazabicyclo[5.4.0]undec-7ene $)^{12}$ and TBAH (tetrabutylammonium hydroxide) ${ }^{12}$ have also been used for this reaction. Sridhar et al. ${ }^{13}$ showed that this reaction can be carried out using Lewis acid catalyst $\left(\mathrm{ZnCl}_{2}\right)$, which shows better results than base catalyzed reactions. Recently, boric acid in combination with cetyl trimethyl ammonium bromide (surfactant) has also been employed for this reaction. ${ }^{14}$

In view of the increasingly strict environment legislation, the present day catalysis research is drifted towards the development of heterogeneous catalysts in aqueous media which are paving the way towards the realization of environmental and eco-friendly synthetic protocols, consequently transforming into greener technology. Iodoxybenzoic acid (IBX) has been drawing attention in synthetic organic chemistry for its promising role as oxidant. Though moderately soluble in organic solvents, it aids in oxidation of alcohols into carbonyl 
Table 1. Screening of the catalysts ${ }^{\mathrm{a}}$

\begin{tabular}{llccc}
\hline entry & Catalyst & Reaction temperature $/{ }^{\circ} \mathrm{C}$ & time $/ \mathrm{h}$ & Yield $/ \%$ \\
\hline 1 & B-cyclodextrin & reflux & 4.0 & 32 \\
2 & ceric ammonium nitrate (CAN) & reflux & 4.0 & 38 \\
3 & ceric ammonium sulfate (CAS) & reflux & 5.0 & 49 \\
4 & tetrabutyl ammonium hydrogen sulfate (TBHS) & reflux & 4.0 & 56 \\
5 & urea-hydrogen peroxide (UHP) & reflux & 3.5 & 58 \\
6 & cuprous chloride (CuCl) & reflux & 3.0 & 60 \\
7 & iodoxybenzoic acid (IBX) & 70 & 1.5 & 80 \\
\hline
\end{tabular}

${ }^{\mathrm{a} C}$ Condition: benzaldehyde $(1 \mathrm{mmol})$, malononitrile $(2 \mathrm{mmol})$, thiophenol $(1 \mathrm{mmol})$, catalyst $(10 \mathrm{~mol} \%)$; ${ }^{\text {bisolated yield. }}$

compounds, ${ }^{15}$ simple phenols to ortho-quinones, ${ }^{16}$ polycyclic aromatic phenols to polycyclic aromatic quinones, ${ }^{17}$ benzocyclic compounds and amines. ${ }^{18}$ Besides this, it is also applied for preparation of carbonyl compounds, ${ }^{18} \mathrm{~N}$-heterocycles ${ }^{18}$ and in oxidative cleavage of dithioacetals and dithioketals. ${ }^{18}$ IBX also offers selective deprotection of triethylsilyl ethers along with tert-butyldimethylsilyl (TBDMS) ethers. ${ }^{19}$

With all these applications of IBX in mind and its mild, chemo-selective nature and our interest in exploring its catalytic properties ${ }^{20}$ prompted us to use it in aqueous medium for the synthesis of 2-amino-3,5-dicarbonitrile6-thiopyridines. The relevance of this methodology stems from the fact that all the aforementioned protocols encounter disadvantages, such as prolonged reaction time, tedious catalyst preparation and workup, formation of inevitable side or sticky products, exhaustive usage of energy sources and solvents that lead to lower yield of desired product and environmental hazard.

Here, we disclose an efficient and environmental benign method for the synthesis of 2-amino-3,5-dicarbonitrile6-thiopyridines in presence of IBX as catalyst in good to excellent yield, as shown in Scheme 1.

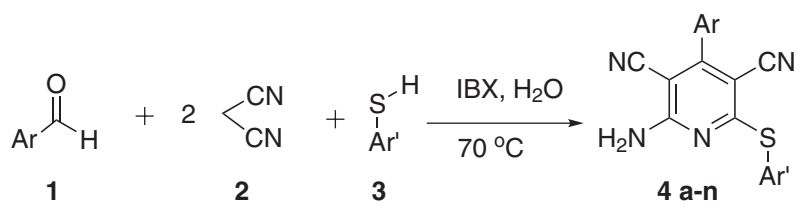

Scheme 1. Synthesis of 2-amino-3,5-dicarbonitrile-6-thiopyridines.

\section{Results and Discussion}

With a view to find optimum reaction conditions for the condensation reaction, preliminary efforts were mainly focused on the evaluation of different catalysts viz. $\beta$-cyclodextrin, ceric ammonium nitrate (CAN), ceric ammonium sulfate (CAS), tetra butyl ammonium hydrogen sulfate (TBHS), urea-hydrogen peroxide (UHP), cuprous chloride $(\mathrm{CuCl})$ and iodoxybenzoic acid (IBX). Table 1 displays the effect of the catalysts on the reaction rate and product yield.

Fast reaction rate and enhanced product yield were observed in the IBX-mediated reaction presumably due to the ability of hypervalent iodine for a coordination complex, resulting into polarization of carbonyl and nitrile groups which speed up the Knoevenagel condensation and Michael addition (first two steps of the multicomponent condensation).

Since IBX is a selective oxidizing agent at its stoichiometric levels, in order to optimize the catalyst quantity, the model reaction was carried out with different quantities of IBX such as 2, 5, 10 and $15 \mathrm{~mol} \% .10 \mathrm{~mol} \%$ of IBX with respect to benzaldehyde was found to be optimal (Table 2).

Table 2. Optimization of iodoxybenzoic acid (IBX) as catalyst ${ }^{\mathrm{a}}$

\begin{tabular}{lcc}
\hline entry & Iodoxybenzoic acid / mol\% & Yield $^{\mathrm{b}} / \%$ \\
\hline 1 & 2 & 40 \\
2 & 5 & 68 \\
3 & 10 & 80 \\
4 & 15 & 80 \\
\hline a'Condition: benzaldehyde (1 mmol), malononitrile (2 mmol), thiophenol \\
(1 mmol), IBX; bisolated yield.
\end{tabular}

All the aforementioned results encouraged us to plan the synthesis of several 2-amino-3,5-dicarbonitrile6-thiopyridines by treating various substituted aromatic aldehydes with malononitrile and thiophenols (Table 3). The products are accomplished in good to excellent yields and their physical and spectral data are in agreement with literature reports. ${ }^{12,14,21}$ Indeed, the method has the ability to tolerate functional groups such as methoxy, nitro, halides, etc.

The recovery and reusability of the catalyst are crucial in environmental benign large scale protocols and 
Table 3. Synthesis of 2-amino-3,5-dicarbonitrile-6-thiopyridines ${ }^{\mathrm{a}}$

\begin{tabular}{|c|c|c|c|c|c|c|}
\hline entry & Compound & $\mathrm{Ar}$ & $\mathrm{Ar}^{\prime}$ & time $/ \mathrm{h}$ & Yield $^{\mathrm{b}} / \%$ & $\mathrm{mp}^{\mathrm{c}} /{ }^{\circ} \mathrm{C}$ \\
\hline 1 & $4 a$ & $\mathrm{Ph}$ & $\mathrm{Ph}$ & 1.5 & 80 & $219-220$ \\
\hline 2 & $4 b$ & 4-Me-Ph & $\mathrm{Ph}$ & 1.5 & 72 & $208-210$ \\
\hline 3 & $4 c$ & 4-OMe-Ph & $\mathrm{Ph}$ & 2.0 & 70 & $242-243$ \\
\hline 4 & $4 d$ & $3,4-(\mathrm{OMe})_{2}-\mathrm{Ph}$ & $\mathrm{Ph}$ & 2.0 & 78 & $229-230$ \\
\hline 5 & $4 e$ & $4-\mathrm{NO}_{2}-\mathrm{Ph}$ & $\mathrm{Ph}$ & 1.5 & 83 & 289-291 \\
\hline 6 & $4 f$ & $4-\mathrm{NO}_{2}-\mathrm{Ph}$ & 2-Br-Ph & 1.5 & 82 & $258-260$ \\
\hline 7 & $4 g$ & 4-Cl-Ph & $\mathrm{Ph}$ & 1.5 & 80 & $222-223$ \\
\hline 8 & $4 h$ & 2,6-Cl-Ph & $2,4,6-\mathrm{Me}_{3}-\mathrm{Ph}$ & 2.0 & 75 & $280-282$ \\
\hline 9 & $4 i$ & 4-Br-Ph & $\mathrm{Ph}$ & 1.5 & 82 & $255-257$ \\
\hline 10 & $4 j$ & 4-Cl-Ph & $2,4,6-\mathrm{Me}_{3}-\mathrm{Ph}$ & 2.0 & 73 & $289-290$ \\
\hline 11 & $4 k$ & $3,4-(\mathrm{OMe})_{2}-\mathrm{Ph}$ & $\mathrm{Ph}$ & 2.0 & 69 & $227-228$ \\
\hline 12 & 41 & $3,4-\mathrm{Me}_{2}-\mathrm{Ph}$ & 2-Me-Ph & 2.0 & 71 & $243-244$ \\
\hline 13 & $4 m$ & 4-Me-Ph & 2-Me-Ph & 2.0 & 70 & $223-225$ \\
\hline 14 & $4 n$ & $3,4-(\mathrm{OMe})_{2}-\mathrm{Ph}$ & 4-Cl-Ph & 2.5 & 72 & 273-275 \\
\hline
\end{tabular}

${ }^{a}$ Condition: benzaldehyde $(1 \mathrm{mmol})$, malononitrile $(2 \mathrm{mmol})$, thiophenol $(1 \mathrm{mmol}), \mathrm{IBX}(10 \mathrm{~mol} \%), \mathrm{H}_{2} \mathrm{O}(5 \mathrm{~mL})$, temperature of $70{ }^{\circ} \mathrm{C}$; bisolated yield; cmp: melting point.

from the industrial point of view. In this protocol, after completion of the reaction, IBX was recovered by simple filtration, washed with little quantity of water and then dried. IBA, the reduction product of IBX obtained upon completion of reaction, was oxidized back to IBX. Thus, gained IBX has revealed identical chemical and physical characteristics to those of standard IBX. In this manner, it was recovered about $55-60 \%$ of IBX and reused for further three successive reaction cycles offering consistent yield of products.

\section{Conclusion}

The present work highlights IBX as an inexpensive, non-corrosive and environmentally benign catalyst for the synthesis of 2-amino-3,5-dicarbonitrile-6-thiopyridines. We anticipate that short reaction time, easy catalyst recovery, aqueous reaction medium and high yield of product could make this protocol a good alternative to the existing protocols.

\section{Experimental}

All commercial reagents were used as received without purification and all solvents were reagent grade. The reaction was monitored by TLC (thin layer chromatography) using on $0.25 \mathrm{~mm}$ E-Merck silica gel $60 \mathrm{~F}_{254}$ precoated plates, which were visualized with UV light. Melting points (mp) were taken in open capillaries on a Veego apparatus and are uncorrected. Infrared spectra were recorded on a Simadzu spectrophotometer in a $\mathrm{KBr}$ disc, and the absorption bands are expressed in $\mathrm{cm}^{-1}$. ${ }^{1} \mathrm{H}$ NMR (nuclear magnetic resonance) spectra were recorded on a Varian AS $300 \mathrm{MHz}$ spectrometer in DMSO- $\mathrm{d}_{6}$, chemical shifts $(\delta)$ are in ppm (parts per million) relative to TMS (tetramethylsilane).

General procedure for the synthesis of 2-amino3,5-dicarbonitrile-6-thiopyridines

A solution of aldehyde (1 mmol), malononitrile $(2 \mathrm{mmol})$ and a thiophenol $(1 \mathrm{mmol})$ in water $(5 \mathrm{~mL})$ was stirred at $70{ }^{\circ} \mathrm{C}$ in the presence of catalytic amount of IBX (10 mol\%, $0.28 \mathrm{~g})$. The progress of the reaction was monitored by TLC. After completion of the reaction, the product was extracted with diethyl ether $(2 \times 5 \mathrm{~mL})$. The combined organic layer was then washed with brine $(2 \times 5 \mathrm{~mL})$, and dried over $\mathrm{MgSO}_{4}$. The solvent was evaporated under reduced pressure and the crude product obtained was purified by column chromatography followed by recrystallization from ethanol. The catalyst was recovered from aqueous layer by simple filtration.

\section{Physical and spectral data of the product}

2-Amino-4-(4-methoxyphenyl)-6-(phenylthio)pyridine3,5-dicarbonitrile (4c)

IR (KBr) v/cm ${ }^{-1} 3437,3327,3228,3074,2926,2220$, 1628,1529 ; ${ }^{1} \mathrm{H}$ NMR (DMSO- $\left.d_{6}, 300 \mathrm{MHz}\right) \delta 3.61$ (s, $3 \mathrm{H}), 7.1(\mathrm{~d}, 2 \mathrm{H}, J 7.8 \mathrm{~Hz}), 7.18-7.20(\mathrm{~m}, 3 \mathrm{H}), 7.7(\mathrm{~d}, 2 \mathrm{H}$, $J 7.8 \mathrm{~Hz}), 7.45$ (d, 2H), 7.78 (s, 2H). 


\section{Supplementary Information}

The spectroscopic ${ }^{1} \mathrm{H}$ NMR and IR data of selected compound are available free of charge at http://jbcs.sbq.org.br as a PDF file.

\section{Acknowledgment}

We appreciate the generous support from Dr. S. T. Gadade, Changu Kana Thakur College, India.

\section{References}

1. Boger, D. L.; Nakahara, S.; J. Org. Chem. 1991, 56, 880.

2. Zhang, T. Y.; Stout, J. R.; Keay, J. G.; Scriven, E. F. V.; Toomey, J. E.; Goe, G. L.; Tetrahedron 1995, 51, 13177.

3. Ma, X.; Gang, D. R.; Nat. Prod. Rep. 2004, 21, 752.

4. Perrier, V.; Wallace, A. C.; Kaneko, K.; Safar, J.; Prusiner, S. B.; Cohen, F. E.; Proc. Nat. Acad. Sci. U. S. A. 2000, 97, 6073; Anderson, D. R.; Stehle, N. W.; Kolodziej, S. A.; Reinhard, E. J.; PCT Int. Appl. WO 2004055015 A1 20040701, 2004; Nirschl, A. A.; Hamann, L. G.; US Pat. Appl. Publ. 2005182105 Al 20050818, 2005

5. Reddy, T. R. K.; Mutter, R.; Heal, W.; Guo, K.; Gillet, V. J.; Pratt, S.; Chen, B.; J. Med. Chem. 2006, 49, 607; May, B. C. H.; Zorn, J. A.; Witkop, J.; Sherrill, J.; Wallace, A. C.; Legname, G.; Prusiner, S. B.; Cohen, F. E.; J. Med. Chem. 2007, 50, 65.

6. Chen, H.; Zhang, W.; Tam, R.; Raney, A. K.; PCT Int. Appl. WO 2005058315 A1 20050630, 2005.

7. Levy, S. B.; Alekshun, M. N.; Podlogar, B. L.; Ohemeng, K.; Verma, A. K.; Warchol, T.; Bhatia, B.; Bowser, T.; Grier, M.; US Pat. Appl. 2005124678 A1 20050609, 2005.

8. Anderson, D. R.; Stehle, N. W.; Kolodziej, S. A.; Reinhard, E. J.; PCT Int. Appl. WO 2004055015 A1 20040701, 2004.

9. Harada, H.; Watanuki, S.; Takuwa, T.; Kawaguchi, K.; Okazaki, T.; Hirano, Y.; Saitoh, C.; PCT Int. Appl. WO 2002006237 Al 20020124, 2002

10. Fredholm, B. B.; Ijzerman, A. P.; Jacobson, K. A.; Klotz, K.-N.; Linden, J.; Pharmacol. Rev. 2001, 53, 527.
11. Guo, K.; Mutter, R.; Heal, W.; Reddy, T. R. K.; Cope, H.; Pratt, S.; Thompson, M. J.; Chen, B.; Eur. J. Med. Chem. 2008, 43, 93 .

12. Evdokimov, N. M.; Magedov, I. V.; Kireev, A. S.; Kornienko, A.; Org. Lett. 2006, 8, 899; Evdokimov, N. M.; Kireev, A. S.; Yakovenko, A. A.; Antipin, M. Y.; Magedov, I. V.; Kornienko, A.; J. Org. Chem. 2007, 72, 3443; Ranu, B. C.; Jana, R.; Sowmiah, S.; J. Org. Chem. 2007, 72, 3152; Mamgain, R.; Singh, R.; Rawat, D. S.; J. Heterocycl. Chem. 2009, 46, 69; Guo, K.; Thompson, M. J.; Chen, B.; J. Org. Chem. 2009, 74, 6999.

13. Sridhar, M.; Ramanaiah, B. C.; Narsaiah, C.; Mahesh, B.; Kumaraswamy, M.; Mallu, K. K. R.; Ankathi, V. M.; Rao, P. S.; Tetrahedron Lett. 2009, 50, 3897.

14. Shinde, P. V.; Sonar, S. S.; Shingate, B. B.; Shingare, M. S.; Tetrahedron Lett. 2010, 51, 1309.

15. Frigerio, M.; Santagostino, M.; Tetrahedron Lett. 1994, 35, 8019; Duschek, A.; Kirsch, S. F.; Angew. Chem. Int. Ed. 2011, 50, 1524; Satam, V.; Harad, A.; Rajule, R.; Pati, H.; Tetrahedron 2010, 66, 7659 .

16. Magdziak, D.; Rodriguez, A. A.; Van De Water, R. W.; Pettus, T. R. R.; Org. Lett. 2002, 4, 285.

17. Harvey, R. G.; Dai, Q.; Ran, C.; Penning, T. M.; J. Org. Chem. 2004, 69, 2024; Ran, C.; Xu, D.; Dai, Q.; Penning, T. M.; Blair, I. A.; Harvey, R. G.; Tetrahedron Lett. 2008, 49, 4531; Harvey, R. G.; Dai, Q.; Ran, C.; Gopishetty, S. R.; Penning, T. M.; Polycycl. Aromat. Comp. 2004, 24, 257.

18. Nicolaou, K. C.; Montagnon, T.; Baran, P. S.; Zhong, Y.-L.; J. Am. Chem. Soc. 2002, 124, 2245; Nicolaou, K. C.; Mathison, C. J. N.; Montagnon, T.; J. Am. Chem. Soc. 2004, 126, 5192.

19. Wu, Y.; Huang, J.-H.; Hu, Q.; Tang, C.-J.; Li, L.; Org. Lett. 2002, 4, 2141.

20. Takale, S.; Parab, S.; Phatangare, K.; Pisal, R.; Chaskar, A.; Catal. Sci. Technol. 2011, 1, 1128; Shaikh, H.; Padalkar, V.; Phatangare, K.; Deokar, H.; Chaskar, A.; Green Chem. Lett. Rev. 2011, 4, 171.

21. Das, B.; Ravikanth, B.; Kumar, A. S.; Kanth, B. S.; J. Heterocycl. Chem. 2009, 46, 1208.

Submitted: December 11, 2011 Published online: March 27, 2012 